\title{
Combined Hyperlipidemia in Transgenic Mice Overexpressing Human Apolipoprotein $\mathrm{Cl}$
}

\author{
Neil S. Shachter, ${ }^{\star}$ Tetsu Ebara, ${ }^{\star}$ Rajasekhar Ramakrishnan, ${ }^{\star}$ George Steiner, ${ }^{\ddagger}$ Jan L. Breslow, ${ }^{\S}$ Henry N. Ginsberg, ${ }^{\star}$ \\ and Jonathan D. Smith ${ }^{\S}$ \\ *Division of Preventive Medicine and Nutrition, Department of Medicine, College of Physicians and Surgeons of Columbia University, \\ New York, New York 10032; ${ }^{\ddagger}$ Departments of Medicine and Physiology, University of Toronto, The Toronto Hospital, Toronto, Ontario, \\ M5G 2 C4 Canada; and ${ }^{\S}$ Laboratory of Biochemical Genetics and Metabolism, The Rockefeller University, New York, New York 10021
}

\begin{abstract}
We have generated transgenic mice over-expressing human apolipoprotein CI (apo CI) using the native gene joined to the downstream 154-bp liver-specific enhancer that we defined for apo E. Human apo CI (HuCI)-transgenic mice showed elevation of plasma triglycerides $(\mathrm{mg} / \mathrm{dl})$ compared to controls in both the fasted $(211 \pm 81$ vs $123 \pm 52, P=$ $0.0001)$ and fed $(265 \pm 105$ vs $146 \pm 68, P<0.0001)$ states. Unlike the human apo CII (HuCII)- and apo CIII (HuCIII)transgenic mouse models of hypertriglyceridemia, plasma cholesterol was disproportionately elevated $(95 \pm 23$ vs $73 \pm$ $23, P=0.002$, fasted and $90 \pm 24$ vs $61 \pm 14, P<0.0001$, fed). Lipoprotein fractionation showed increased VLDL and IDL+ LDL with an increased cholesterol/triglyceride ratio $(0.114$ vs $0.065, P=0.02$, in VLDL). The VLDL apo E/apo B ratio was decreased 3.4-fold $(P=0.05)$ and apo CII and apo CIII decreased in proportion to apo $\mathrm{E}$. Triglyceride and apo $\mathrm{B}$ production rates were normal, but clearance rates of VLDL triglycerides and postlipolysis lipoprotein "remnants" were significantly slowed. Plasma apo B was significantly elevated. Unlike HuCII- and HuCIII-transgenic mice, VLDL from HuCI transgenic mice bound heparin-Sepharose, a model for cell-surface glycosaminoglycans, normally. In summary, apo CI overexpression is associated with decreased particulate uptake of apo B-containing lipoproteins, leading to increased levels of several potentially atherogenic species, including cholesterol-enriched VLDL, IDL, and LDL. $(J$. Clin. Invest. 1996. 98:846-855.) Key words: apolipoprotein C - hypertriglyceridemia - lipoproteins, LDL • lipoproteins, VLDL $\bullet$ mice, transgenic
\end{abstract}

\section{Introduction}

Our understanding of the small apolipoproteins of VLDL, apo $\mathrm{C}$, has progressed with advances in protein purification and

Address correspondence to Neil S. Shachter, Division of Preventive Medicine and Nutrition, Department of Medicine, College of Physicians and Surgeons of Columbia University, 630 W. 168th Street, New York, NY 10032. Phone: 212-305-3741; FAX: 212-305-5384; E-mail: nss5@columbia.edu

Received for publication 23 October 1995 and accepted in revised form 28 May 1996

J. Clin. Invest.

(C) The American Society for Clinical Investigation, Inc. 0021-9738/96/08/0846/10 \$2.00

Volume 98, Number 3, August 1996, 846-855 molecular biology. Apo $\mathrm{C}$ was found to consist of three proteins with distinct properties $(1,2)$. Apo CII was shown to be the obligatory activator of lipoprotein lipase (LPL) $(3,4)$ while apo CIII and apo CI had an inhibitory effect on lipoprotein lipase activity $(4,5)$. The role of apo CIII in elevating triglycerides has now been extensively validated by clinical observation (6-8), the study of the deficiency state (9), genetic linkage studies (10), and both transgenic (11-13) and knockout mice (14). Human apo CII transgenic (HuCII Tg) $)^{1}$ mice were surprising in showing an apparent lipolytic defect similar to that of the HuCIII Tg mice (15). Apo CI, along with apo CII and apo CIII, has been shown to displace apo E from triglyceriderich emulsions and lipoproteins, and to interfere with their hepatic clearance $(16,17)$. In addition, there is direct evidence that apo CI can interfere with lipoprotein-receptor interaction. Either mixed apo Cs or purified apo CI decreased binding of $\beta$-migrating VLDL to a remnant receptor, the LDL receptorrelated protein $(18,19)$. Each of the apo Cs has also been shown to decrease the apo E-mediated binding of human VLDL and IDL to the LDL receptor, with apo CI most effective $(20,21)$.

Information regarding plasma lipid levels in human $\mathrm{HuCI}$ $\mathrm{Tg}$ mice was reported by Simonet et al. in a study establishing the role of DNA sequences $5^{\prime}$ to the apo $\mathrm{CI}^{\prime}$ pseudogene in the liver-specific expression of apo CI and apo E (22). Plasma levels of both triglycerides and cholesterol were moderately elevated. Apo CI-gene knockout mice have also been reported and, unexpectedly, were found to have modestly elevated triglycerides $(\sim 60 \%)$ while cholesterol levels remained normal (23). On a high fat diet, plasma cholesterol (mainly in the VLDL-LDL range of fractions on gel filtration chromatography) increased more in the knockout mice than in controls. VLDL from the knockout mice competed poorly against human LDL for binding to the human LDL receptor when compared to wild-type (WT) VLDL. The results were interpreted as indicating a remnant removal defect in the knockout mice; surprising, in view of the earlier physiological data showing that apo CI interfered with remnant clearance.

In light of these seemingly contradictory findings, we elected to perform further investigations of the role of apo CI in the metabolism of triglyceride-rich lipoproteins. We now report the introduction of a human apo CI transgene into mice and demonstrate that the 154-bp minimal liver-specific enhancer that we defined for apo $\mathrm{E}$ is sufficient for apo CI transgene expression in liver (24). We have also characterized the

1. Abbreviations used in this paper: CHYLOS, chylomicrons; FCR, fractional catabolic rate; HuCI, human apo CI; IEF, isoelectric focusing; Tg, transgenic; WT, wild type. 
effects of excess apo CI on lipoprotein phenotype and metabolism. HuCI Tg mice are moderately hypertriglyceridemic and hypercholesterolemic. VLDL and IDL+LDL are increased and cholesterol-enriched, associated with decreased clearance of VLDL triglycerides and lipoprotein remnants.

\section{Methods}

Plasmid construction. Standard recombinant DNA techniques were employed. Cosmid 4, containing the human apo CI gene and downstream sequences, was the gift of Marten H. Hofker (25). A SalI/ BamHI DNA fragment bracketing the apo CI gene was cloned with and without the PvuII-ApaI 154-bp liver-specific enhancer located 5' to the apo $\mathrm{CI}^{\prime}$ pseudogene (24), which was inserted into the BamHI site. Plasmids were prepared by alkaline lysis and banded twice through cesium chloride-ethidium bromide gradients.

Transgenic mice. DNA inserts were obtained by SalI/EcoRI digestion and $0.7 \%$ agarose gel electrophoresis. DNA was extracted from the gel using Qiaex resin (Qiagen, Inc., Chatsworth, CA). Transgenic mice were created as previously described (26). The fertilized eggs microinjected with the DNA construction were (C57BL/ $6 \mathrm{~J} \times \mathrm{CBA} / \mathrm{J}) \mathrm{F}_{2}$. Integration of the human apo $\mathrm{CI}$ gene was determined by PCR of tail-derived DNA. Subsequent screening was done using the human apo CI Western blot described below.

Animals. Animals were caged in an approved animal care facility with a 7:00 a.m. to 7:00 p.m. period of light. Except as indicated, animals were fed a standard mouse chow diet containing $4.5 \%$ fat ( $9 \%$ of calories) and $0.02 \%$ cholesterol (Ralston Purina Co., St. Louis, MO). Access to food was ad lib, except for fasting blood specimens. Both male and female mice were used in approximately equal ratios in all experiments, except where specified. Animals were anesthetized with methoxyflurane for retroorbital phlebotomy and intravenous femoral injections. $100 \mu \mathrm{l}$ of plasma were used for analyses, and animals were allowed to recover for $10 \mathrm{~d}$ between phlebotomies.

$\mathrm{F}_{1}$ mice were bred to homozygosity, as defined by $100 \%$ transmission of the transgene by an $\mathrm{F}_{2}$ mouse to its $\mathrm{F}_{3}$ offspring. Documented homozygous $\mathrm{F}_{2}$ mice, along with their nontransgenic littermates were used to develop populations of obligate homozygotes, hemizygotes, and WT control mice of otherwise similar genetic background. Phlebotomy times were based on the nocturnal feeding behavior of mice. Plasma cholesterol and triglycerides were determined at 9:00 a.m. ("fed state") and at 5:00 p.m. after the removal of food at 8:00 a.m. ("fasted state") on both the chow and "Western-type" high fat diet ( $21 \%$ fat by wt, $42 \%$ by calories, and $0.15 \%$ cholesterol) diets (27). The animals were 2-3 mo old when the "chow" bloods were obtained and 3-4 mo old when studied on the high fat diet.

Statistics. All comparisons were by $t$ test; comparisons between the same animals in different states were by paired $t$ test. Two-tailed $P$ values are reported.

RNase protection assay. The human apo CI cRNA probe was derived by cloning nucleotides $115-336$ of the human apo CI cDNA (28) into pGEM1. Orientation was determined by restriction digestion. RNase protection assay was performed as described on $10 \mathrm{mg}$ of total RNA extracted from the tissues of male high expressing animals (29). The autoradiogram was scanned using a laser densitometer (LKB, Uppsala, Sweden).

Western blot. Mouse plasma samples and dilutions of a human apo CI standard (kindly provided by Petar Alaupovic) were run on a $16 \%$ polyacrylamide SDS gel in a Tris-Tricine buffer system (Novex, San Diego, CA). The gels were electroblotted onto nitrocellulose and the blots were stained with a mouse monoclonal anti-human apo CI (Organon Teknika, Durham, NC) and goat anti-mouse IgG linked to horseradish peroxidase. Blots were developed with ECL reagent (Amersham Corp., Arlington Heights, VA), exposed to film and scanned as above.

Human apo CI levels. Plasma human apo CI levels were obtained by electroimmunoassay in the laboratory of P. Alaupovic, as de- scribed (30). The animals were 2 mo old for the chow levels and 3 mo old for the high fat diet levels.

Lipoprotein analysis. Triglyceride and cholesterol concentrations were performed using commercial kits (Boehringer Mannheim Biochemicals, Indianapolis, IN) on an autoanalyzer (705; Hitachi Ltd., Tokyo). Phospholipids were determined using a commercial kit (Phospholipids B; Wako Pure Chemical Industries, Ltd., Osaka, Japan). VLDL $(d<1.006 \mathrm{~g} / \mathrm{ml})$, IDL+LDL $(d=1.006-1.063 \mathrm{~g} / \mathrm{ml})$, and HDL $(d=1.063-1.21 \mathrm{~g} / \mathrm{ml})$, were separated by sequential density ultracentrifugation of pooled mouse plasma (31). The animals were 4-6 mo old and, in both groups, were predominantly male (80\%). Protein concentrations in lipoprotein fractions were determined by the BCA protein assay (Pierce Chemical Co., Rockford, IL). Gel filtration chromatography was performed on $200 \mu$ l of pooled mouse plasma, obtained in the fed state from mice that were 4-5 mo old, using two Superose 6 columns in series (FPLC; Pharmacia LKB Biotechnology Inc., Piscataway, NJ). 0.5-ml fractions were collected, and cholesterol and triglyceride levels were determined using enzymatic reagents (Boehringer Mannheim Corp.) in an assay modified for a 96well plate format. Relative apo CI levels in the fractions were determined by Western blot. FPLC fractions are dilute; the FPLC data are qualitative because of the threshold of sensitivity of the assays applied to the fractions.

Free cholesterol assay. Five $\mathrm{HuCI} \mathrm{Tg}$ mice and five controls (6 mo old, one male and four females) were bled as described above $(400 \mu \mathrm{l})$ between 2:00 and 3:00 p.m., after the removal of food at 8:00 a.m. Samples were kept on ice and the plasma was promptly separated after brief centrifugation in a refrigerated microcentrifuge. Aliquots of plasma were then frozen at $-70^{\circ} \mathrm{C}$. Samples were defrosted on wet ice and assayed in duplicate for free cholesterol and total cholesterol using kits (Wako Free Cholesterol C and Cholesterol CII; Wako Pure Chemical Industries, Ltd.).

Apolipoprotein analysis. Apo B100, apo B48, and apo E were quantitated via a $5-\mu \mathrm{g}$ SDS-PAGE on lipoprotein protein from $6 \mathrm{WT}$ and $6 \mathrm{HuCI} \mathrm{Tg}$ pools of VLDL using 4-20\% gels run in Tris-glycine buffer. Apos CI, CII/CIII, AI, and E were resolved on 2 WT and 3 $\mathrm{HuCI} \mathrm{Tg}$ pools using precast $10-20 \%$ polyacrylamide gradient gels with a $3 \%$ stacking gel (Bio-Rad Laboratories, Richmond, CA) run in Tris-Tricine buffer. Gels were fixed overnight in $50 \%$ methanol, $10 \%$ acetic acid and were stained using either silver stain (Bio-Rad Laboratories) (LDL, three pools) according to the manufacturer's protocol, or Coomassie Blue (VLDL, 6 pools and HDL, 3 pools) as follows: staining for $2 \mathrm{~h}$ in $50 \%$ methanol, $10 \%$ acetic acid, $0.05 \%$ Coomassie Brilliant Blue 250 and destaining overnight in 5\% methanol, $7 \%$ acetic acid. The gels were scanned using a laser densitometer and Image QuaNT software (Molecular Dynamics, Inc., Sunnyvale, CA). The "local median" of background, based on a box drawn around the band, was subtracted from the scanned densities. Density measurements of apo B100 and apo B48 were normalized to molecular weight for the calculation of apo B48/total apo B ratios. No adjustment was made for differential chromogenicity of the proteins, limiting our conclusions to relative changes in apolipoprotein composition.

Isoelectric focusing (IEF). VLDL was isolated from pooled plasma from $24 \mathrm{WT}, 5 \mathrm{HuCI} \mathrm{Tg}, 5 \mathrm{HuCII} \mathrm{Tg}$, and $5 \mathrm{HuCIII} \mathrm{Tg}$ mice of both sexes and on average age of 8 mo. Normal human VLDL was also obtained for comparison. VLDL was delipidated as described (32). Protein was measured on the redissolved mouse VLDL apoproteins using the BCA protein assay (Pierce Chemical Co.). This assay primarily detects cysteine, tyrosine, and tryptophan in peptide linkages. It would not detect apo B, which would not redissolve and would only minimally detect apo CI, which contains only one tryptophan residue and no cysteine or tyrosine. IEF (tube gel technique) and gel image densitometry were performed on $70 \mu \mathrm{g}$ of VLDL apoproteins from each pool, as described (33).

Preparation of triglyceride-labeled VLDL. ${ }^{3} \mathrm{H}$-labeled VLDL was produced by in vivo labeling using $\left[{ }^{3} \mathrm{H}\right]$ oleic acid as described (15). The radiolabeled VLDL $(d<1.006 \mathrm{~g} / \mathrm{ml})$ was isolated from two sequential 18 -h ultracentrifugal spins at $38,000 \mathrm{rpm}$ in a $50.4 \mathrm{ti}$ rotor 
(Beckman Instruments, Inc., Fullerton, CA). $300 \mu \mathrm{g} / \mathrm{ml}$ of fatty acidfree albumin (A-7030; Sigma Chemical Co., St. Louis, MO) was added to the density solution to bind unincorporated free fatty acids.

$V L D L$ triglyceride clearance studies. Turnover studies were done in 8-mo-old WT and homozygous HuCI Tg mice, essentially as described (12). Triglyceride-labeled VLDL was prepared as described above. Animals were studied with VLDL from their own genotype. It has been demonstrated that the turnover of radiolabeled VLDL in mice reflects the characteristics of the VLDL of the recipient mouse, presumably due to the rapid exchange of small apolipoproteins (12). We did our experiments with homologous tracers because of the general principle of kinetic modeling that the tracer be a model for the tracee. Studies were done between 10:00 a.m. and 2:00 p.m. Four control and four HuCI Tg mice were injected with $200,000 \mathrm{cpm}{ }^{3} \mathrm{H}$-labeled VLDL. The disappearance of labeled VLDL was determined by counting 40- $\mu \mathrm{l}$ samples of plasma obtained from $90-\mu \mathrm{l}$ aliquots of blood drawn at 2, 5, 10, 20, 40, 75, and 120 min after injection. Total plasma radioactivity at each time point primarily represents VLDL radioactivity, as has been experimentally validated (12). The data were modeled by a single pool model of triglyceride kinetics exhibiting one phase exponential decay to a plateau, essentially as has been described $(12,34)$. Individual fractional catabolic rates (FCRs) were calculated for each animal and used to determine the mean FCR of each group. Modeling and statistical analysis was done with Prism and InStat software (GraphPAD Software for Science, San Diego, CA). We did not compensate for hemodilution, which may have increased our estimate of rates of clearance, but this effect would be expected to be comparable in both groups and would not affect the comparison of the two genotypes.

Triglyceride production rates. Five control and five 4-mo-old $\mathrm{HuCI} \mathrm{Tg}$ mice (four males and one female in each group) were anesthetized and injected with $500 \mathrm{mg} / \mathrm{kg}$ Triton WR 1339 i.v. (Tyloxapol, T-8761; Sigma Chemical Co.) as a $15-\mathrm{g} / \mathrm{dl}$ solution in $0.9 \% \mathrm{NaCl}$. An equal number of mice from both groups was always studied on any given day (between 10:00 a.m. and 2:00 p.m.). Plasma VLDL clearance in mice is essentially completely inhibited in both control and hypertriglyceridemic mice under these conditions, and the rise in plasma triglyceride levels between the two time points reflects production only (12). Studies were done in the fasted state between noon and 2:00 p.m. 60- $\mu \mathrm{l}$ blood samples were drawn at 30 and $60 \mathrm{~min}$ after the injection. Triglycerides were measured on the separated plasma. Production rates were estimated via the difference between the 30and 60-min triglyceride values and compared by two-tailed $t$ test.

Free fatty acid assay. Levels were obtained on 4-mo-old mice (four male, one female in each group). Blood was drawn by capillary tube bleeding into cold Eppendorf tubes containing EDTA and placed on ice. The plasma was promptly separated and nonesterified fatty acids were immediately measured using the NEFA-C kit (Wako Pure Chemical Industries, Ltd.).

Apo B "remnant" clearance studies. Remnant clearance was estimated by measuring the fractional catabolic rate of apo B in VLDL isolated from apo E-null (apo $\mathrm{E}_{0}$ ) mice. The assay was performed in male 8-mo-old animals. VLDL were isolated from apo $\mathrm{E}_{0}$ mice, as described above, and labeled with ${ }^{125} \mathrm{I}$ by the iodine monochloride method, as modified for lipoproteins (35). After radioiodination, SDS-PAGE of the tracer revealed that $18 \%$ of the label was present on apo B48. Apo B100 could not be detected. $60 \mu 1$ of blood was obtained at 2, 20, 40, 75, and $120 \mathrm{~min}$ after tracer injection. Aliquots of the separated plasma were then run on a $3-15 \%$ gradient SDS-PAGE with prestained high molecular weight standards (Pharmacia LKB Biotechnology Inc.). The gel was then dried and exposed to film. The visualized apo B48 bands were cut out of the gel and radioactivity was determined in a $\gamma$-counter. Data were modeled as described above for the VLDL triglyceride clearance study. We studied equal numbers of control and transgenic mice (fed a chow diet) on each day and with each labeled lipoprotein preparation.

Mouse Apo B levels. Mouse apo B levels were performed by Levine and Williams as described (36).
Apo B production rates. Apo B production rates were estimated by in vivo labeling in 5-mo-old mice. $150 \mu \mathrm{l}$ of blood was obtained 60 and 90 min after the injection of Triton WR 1339, as above, and 200 $\mu \mathrm{Ci}$ of Pro-mix (SJQ 0079; Amersham Corp.), an L-[ $\left.{ }^{35} \mathrm{~S}\right]$ methionine and $\mathrm{L}-\left[{ }^{35} \mathrm{~S}\right]$ cysteine mixture, into five $\mathrm{WT}$ and five homozygotic HuCI Tg mice. $100 \mu \mathrm{l}$ of $d=1.006$ solution was overlaid on $50 \mu \mathrm{l}$ plasma and then spun for $3 \mathrm{~h}$ in an airfuge (Beckman Instruments, Inc.). 125 $\mu \mathrm{l}$ of the bottom was then removed with a Hamilton syringe. A fraction of the (residual) VLDL was then loaded on an SDS gel based on normalization to TCA-precipitable counts in whole plasma. The gels were stained with Coomassie Blue and the apo B bands were visualized, dried, confirmed by autoradiography, and then cut out and counted in $10 \mathrm{ml}$ Hydrofluor (National Diagnostics, Atlanta, GA) in a scintillation counter (LS 1800; Beckman Instruments, Inc.). Apo B production was estimated from the cpm of apo B48+apo B100.

$V L D L$ binding assay. VLDL heparin affinity was measured essentially as has been described (15). ${ }^{3} \mathrm{H}$-labeled VLDL was isolated from 36 mice: three separate pools of plasma (each pool from three mice) for each of WT, HuCI Tg, HuCII Tg, and HuCIII Tg mice. Each preparation was diluted $\sim 20$-fold to $50 \mu \mathrm{g}$ protein $/ \mathrm{ml}$ in 100 $\mathrm{mM}$ Tris, $100 \mathrm{mM} \mathrm{NaCl}, 2 \mathrm{mM} \mathrm{CaCl}_{2}$, BSA $0.2 \mathrm{~g} / \mathrm{dl}, \mathrm{pH} 7.4$, and then incubated for $2 \mathrm{~h}$ at $37^{\circ} \mathrm{C}$ with an equal volume $(0.5 \mathrm{ml})$ of heparinSepharose gel (CL-6B; Pharmacia LKB Biotechnology Inc.), preswollen in the same buffer. The heparin-Sepharose gels were pelleted and the buffer was removed. The subsequent washing step was more vigorous than previously, leading to lower total binding in all groups. Gels were fully resuspended three times with binding buffer. Buffer containing $1,000 \mathrm{U} / \mathrm{ml}$ of heparin was then added and the gels were incubated at $37^{\circ} \mathrm{C}$ for $10 \mathrm{~min}$. The buffer was removed and the ${ }^{3} \mathrm{H}$ counts per minute in the gel, heparin eluate, and original VLDL preparation were determined, allowing the calculation of the percentage of VLDL bound to the gel along with the heparin-elutable fraction. The experiment was performed in triplicate for each preparation.

\section{Results}

Production of human apo CI transgenic mice and resultant hyperlipidemia. A DNA fragment extending from $3 \mathrm{~kb} 5^{\prime}$ to 2.5 $\mathrm{kb} 3^{\prime}$ to the apo CI gene was joined to the 154-bp liver-specific enhancer located $5^{\prime}$ to the apo CI' pseudogene. We previously described this enhancer as sufficient for the liver-specific expression of a human apo E transgene (24). This DNA construction and an identical construction lacking the enhancer were microinjected into $\mathrm{C} 57 \mathrm{BL} / 6 \times \mathrm{CBA} \mathrm{F}_{2}$ fertilized ova and two transgenic lines were established for each. Total RNA

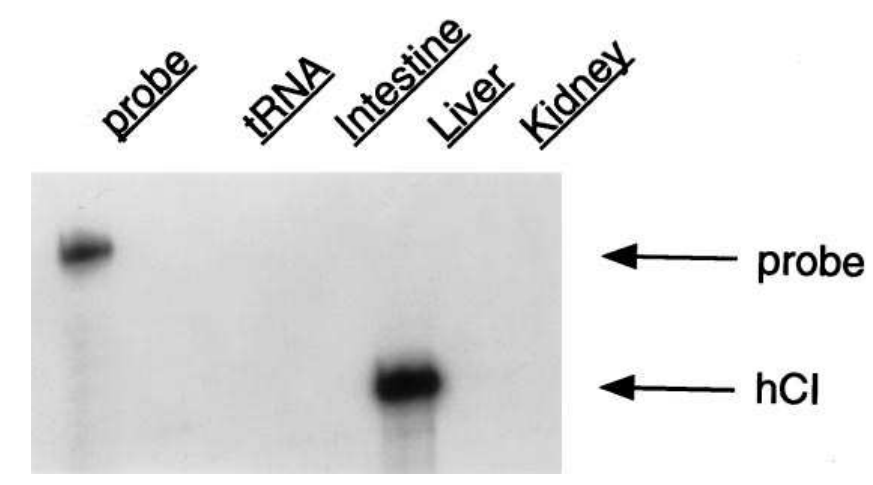

Figure 1. RNase protection gel assay. The full length human apo CI cRNA probe and the fragment protected by that probe are shown. The human apo CI transgene is expressed robustly in the liver. No expression is evident in intestine, kidney, or brain (not shown). 
Table I. Human Apo CI Transgenic Mice: Summary of Plasma Lipids ( $m g / d l \pm S D)$

\begin{tabular}{|c|c|c|c|c|c|}
\hline & \multirow{2}{*}{$\begin{array}{c}\text { WT } \\
n=20\end{array}$} & \multicolumn{2}{|c|}{ Hemizygotes } & \multicolumn{2}{|c|}{ Homozygotes } \\
\hline & & $n=14$ & $P$ & $n=24$ & $P$ \\
\hline CHOL, fed state & $61 \pm 14$ & $74 \pm 17$ & $0.018^{*}$ & $90 \pm 24$ & 0.000001 \\
\hline TG, fed state & $146 \pm 68$ & $185 \pm 61$ & 0.006 & $265 \pm 105$ & 0.00001 \\
\hline $\mathrm{CHOL}$, fasted state & $73 \pm 23$ & $72 \pm 17$ & 0.23 & $95 \pm 23$ & 0.002 \\
\hline TG, fasted state & $123 \pm 52$ & $127 \pm 42$ & 0.81 & $211 \pm 81$ & 0.0001 \\
\hline CHOL, fed high fat & $118 \pm 28$ & $134 \pm 44$ & 0.21 & $180 \pm 58$ & 0.0001 \\
\hline TG, fed high fat & $140 \pm 43$ & $176 \pm 79$ & 0.13 & $233 \pm 120$ & 0.001 \\
\hline $\mathrm{CHOL}$, fasted high fat & $130 \pm 33$ & $153 \pm 66$ & 0.22 & $195 \pm 485$ & 0.000005 \\
\hline TG, fasted high fat & $126 \pm 56$ & $152 \pm 55$ & 0.17 & $202 \pm 64$ & 0.0002 \\
\hline
\end{tabular}

*All statistical comparisons are with the wild type (WT). CHOL, cholesterol; TG, triglycerides.

from liver, brain, intestine, and kidney was assayed for human apo CI mRNA by an RNase protection assay. Both transgenic lines containing the enhancer expressed human apo CI mRNA robustly in the liver, but not in the other tissues. One of the two enhancerless lines expressed the transgene only in the small intestine, while the other line failed to express. An RNase protection gel assay on the higher expressing liver-specific line is shown in Fig. 1. We used this line in all subsequent investigations.

Fasting human apo CI levels on a chow diet in homozygous transgenic mice were $17 \pm 13 \mathrm{mg} / \mathrm{dl}$, vs a normal human level of $9.0 \pm 2.6 \mathrm{mg} / \mathrm{dl}(37)$, and increased to $40 \pm 13 \mathrm{mg} / \mathrm{dl}(P<0.001)$ in the fed state. Human apo CI levels in the fasted state on the Western-type diet were elevated about threefold compared to the chow diet, to $54 \pm 12 \mathrm{mg} / \mathrm{dl}(P<0.00002)$ and increased further to $68 \pm 17 \mathrm{mg} / \mathrm{dl}$ in the fed state $(P<0.003$ vs the chow diet fed state and $P=0.10$ vs the Western diet fasted state). Human apo CI mRNA levels in liver were compared by RNase protection assay on both the chow and Western diets and found to be essentially identical ( $n=2$ for each), suggesting a posttranscriptional mechanism for this difference (data not shown).

Plasma lipids were determined in both the fasted and fed states on both "chow" and a moderately high fat Western-type diet, as shown in Table I. Plasma lipid alterations in hemizygotes were slight and in most cases did not reach statistical significance while the changes in the homozygotes were highly significant. In the homozygous $\mathrm{HuCI} \mathrm{Tg}$ mice, triglycerides were elevated by about $75 \%$ in both the fasted and fed states. Cholesterol levels were elevated by about $50 \%$, well beyond that attributable to increases in triglyceride-rich lipoproteins, as judged by values seen previously in the hypertriglyceridemic apo CIII and apo CII transgenic mice $(12,15)$. On the high fat diet, triglycerides were unchanged in the WT mice and decreased slightly in HuCI Tg mice $(P=$ NS). While absolute cholesterol levels increased to a greater extent in the transgenic mice, the relative increase in cholesterol between the chow and high fat diets revealed no difference between WT and $\mathrm{HuCI} \mathrm{Tg}$ mice. Cholesterol was slightly lower in the fed state than the fasted state, but the relative change was not significantly influenced by either genotype or diet.

Because apo CI is an activator of lecithin:cholesterol acyltransferase (LCAT) (38), we considered the possibility that the increased plasma cholesterol was reflective of increased plasma cholesteryl esters due to cholesterol esterification independent of HDL. The free/total cholesterol ratios were, in fact, found to be indistinguishable $(0.27 \pm 0.06$ in WT vs $0.29 \pm 0.04$ in transgenic mice, $n=5$ of each type, $P=\mathrm{NS}$ ).

Lipoprotein and apolipoprotein profiles in $\mathrm{HuCI} \mathrm{Tg}$ mice. Gel filtration chromatography was performed in the "fed" state (9:00 a.m. postabsorptive) on whole plasma with assay of fractions for cholesterol and triglycerides as well as human apo CI (immunoblot). Results are shown in Fig. 2. A predominant increase in VLDL (cholesterol and triglycerides) was noted in

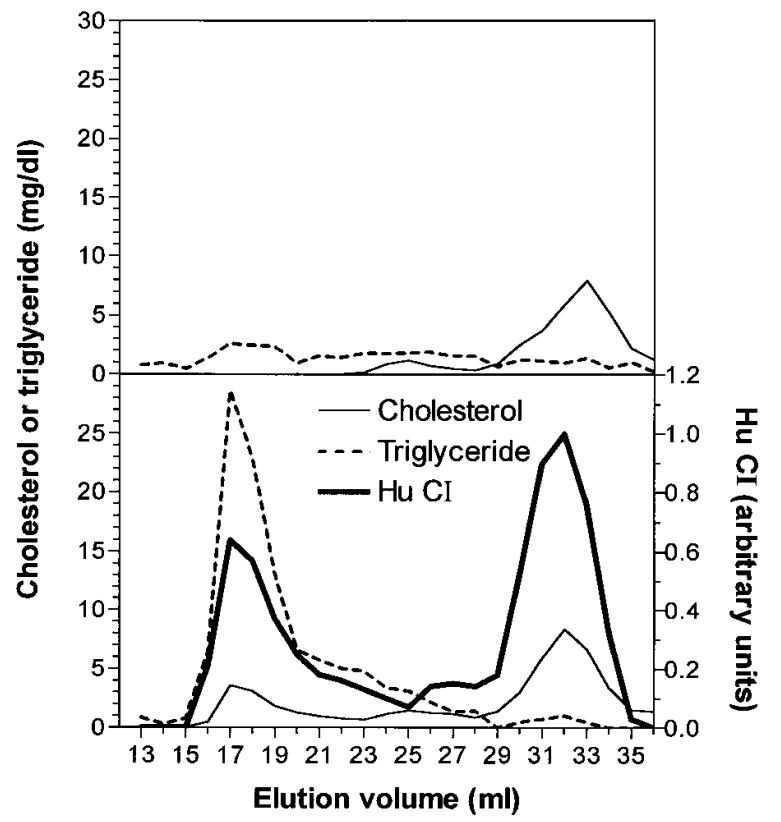

Figure 2. Gel-filtration chromatography of whole plasma from WT (top) and HuCI Tg (bottom) mice on chow diet (fed state). Fractions were analyzed for cholesterol and triglycerides on the left scale, and human apo $\mathrm{CI}(\mathrm{HuCI})$, on the right scale. The human apo CI levels are relative with the highest peak set at 1.0. Fractions 14-20 correspond to chylomicrons and VLDL; 21-24, IDL; 25-28, LDL; and 2935, HDL. Increased VLDL triglycerides and cholesterol, increased IDL triglycerides, and increased LDL cholesterol are noted. 


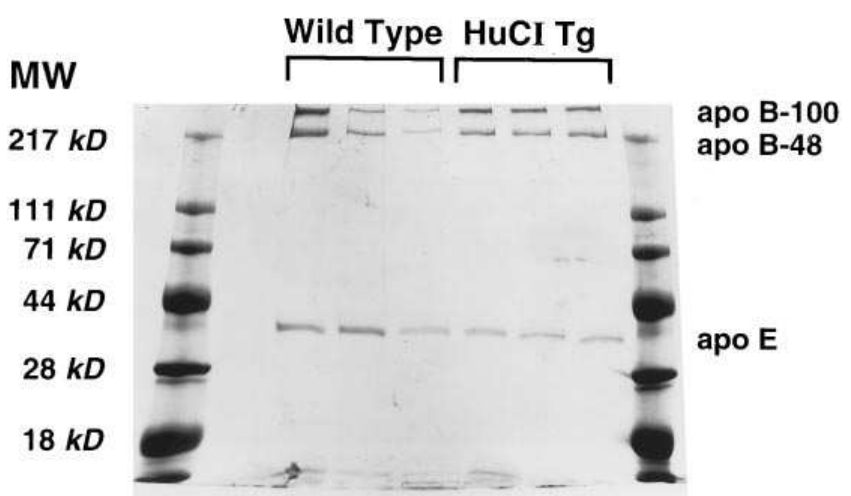

Figure 3. SDS-PAGE of VLDL apolipoproteins. VLDL from three distinct plasma pools (fed state) from WT mice and three from $\mathrm{HuCI}$ $\mathrm{Tg}$ mice are shown along with molecular weight standards on both sides. Locations of the apo B-100, apo B-48, and apo E bands are noted. Decreased apo E relative to apo B is noted in $\mathrm{HuCI}$ Tg mice.

HuCI Tg mice compared to the WT. IDL triglycerides and LDL cholesterol were also increased. The human apo CI, by immunoblot, was about 2/3 in HDL and $1 / 3$ in VLDL.

Lipoprotein fractions were isolated by sequential ultracentrifugation from three pools (six for VLDL), each containing plasma from three mice, for both WT and homozygous mice on chow in the fed state. Results appear in Table II. The lipoprotein profile showed an increase in the chylomicron $(\mathrm{CHY}-$ LOS) + VLDL cholesterol (2.8-fold) and triglyceride (1.6-fold) in the transgenics, compared to WT. The cholesterol to triglyceride ratio in $\mathrm{HuCI} \mathrm{Tg}$ CHYLOS+VLDL was increased to $0.114 \pm 0.021$ from $0.065 \pm 0.0036$ in the WT, $P=0.014$. The IDL+LDL fraction of HuCI Tg mice was also markedly cholesterol enriched, with IDL+LDL cholesterol increasing 2.6fold relative to a 1.4-fold increase in triglycerides. Over half the increase in plasma cholesterol was in CHYLOS+VLDL, with the remainder equally divided between IDL+LDL and HDL. The changes in HDL were not statistically significant and, as in the gel filtration fractions, most of the plasma cholesterol remained in HDL. The changes in CHYLOS+VLDL and IDL+LDL, in particular for cholesterol, were statistically significant.

Apolipoprotein ratios in the lipoprotein fractions were compared using SDS-PAGE. Apolipoproteins in VLDL from six distinct plasma pools were analyzed for both WT and HuCI Tg mice. A representative gel is shown in Fig. 3. A constant amount of VLDL protein was loaded so the intensities of the apo B do not reflect amounts of apo B in whole plasma. The apo B48/apo B100 ratio, by intensity of Coomassie staining, was unchanged in transgenic VLDL $(1.68 \pm 0.19$ in the WT vs $1.52 \pm 0.14$ in HuCI Tg, $P=\mathrm{NS}$ ). The apo E/total apo B ratio, by the same technique, was $1.566 \pm 1.073$ in WT mice and decreased 3.4-fold to $0.465 \pm 0.111$ in transgenics $(n=6, P=$ $0.05)$. The decrease in apo E/apo B ratio reflected increased apo $\mathrm{B}$ as well as decreased apo E.

A portion of the samples was analyzed for C apolipoprotein composition on separate gels (data not shown). The apo CI band intensity in HuCI Tg VLDL was 2.7-fold elevated vs the WT $(P<0.03)$, while the intensity of the apo CII+apo CIII band was $61 \%$ of the WT sample $(P<0.005)$. Apo E in the HuCI Tg VLDL was similarly reduced to $55 \%$ of the WT. The ratio of apo CII+apo CIII to apo E was essentially the same, 0.81 in HuCI Tg and 0.73 in WT VLDL.

Other than the increase in total apo CI, there was no compositional difference in the HuCI Tg vs the WT IDL+LDL fractions, which contained apo B100, apo E, and apo AI without detectable apo B48. The HDL fraction gels predominantly showed apo AI with a modest increase in apo CI, consistent with the high levels of apo AI relative to other apolipoproteins in mouse HDL (data not shown).

Table II. Lipoprotein Profile: WT and Human Apo CI Transgenic Mice*

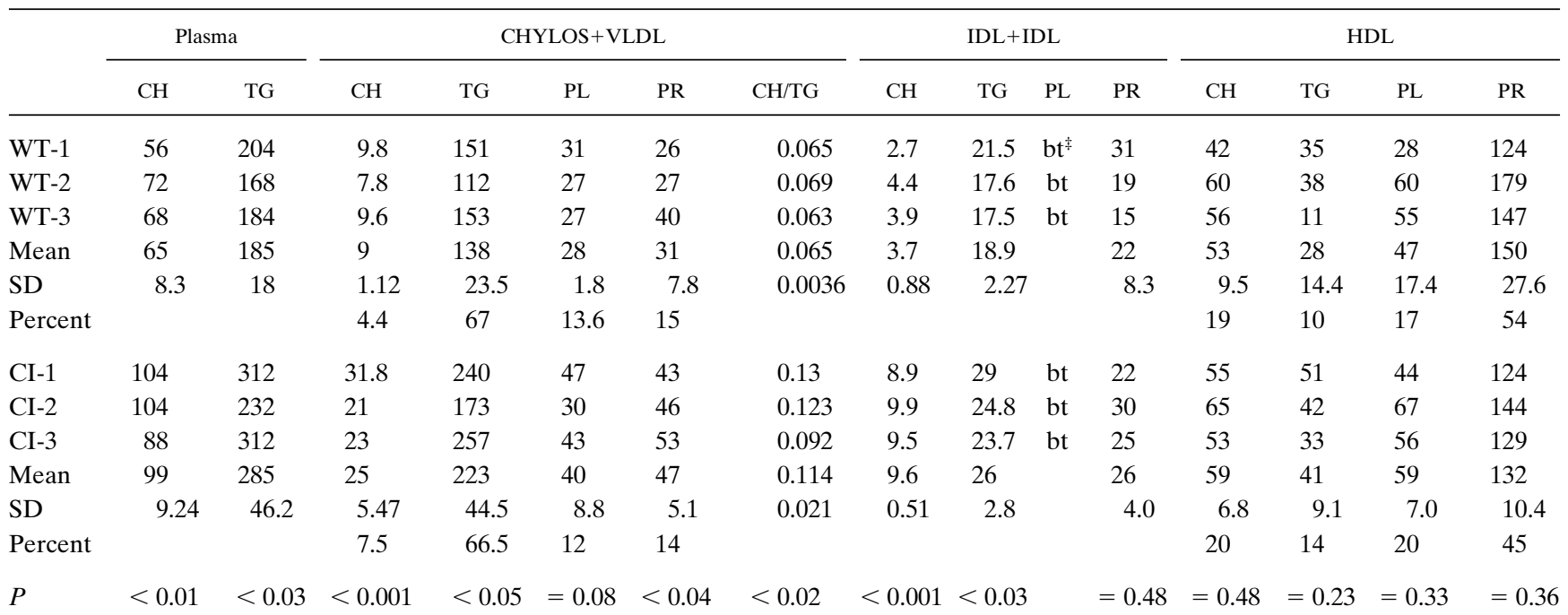

*Values are in $\mathrm{mg} / \mathrm{dl}$. All derived numbers are based on values before rounding. Values are presented based on their representation in whole plasma. VLDL and LDL values have been adjusted based on the recovery of triglycerides and HDL values based on the recovery of cholesterol. The ratio of cholesterol to triglyceride in the fractions is unaltered. Statistics refer to WT vs human apo CI transgenic. ${ }^{*}$ Below threshold of accuracy of assay. CH, cholesterol; TG, triglycerides; PL, phospholipids; PR, protein. 


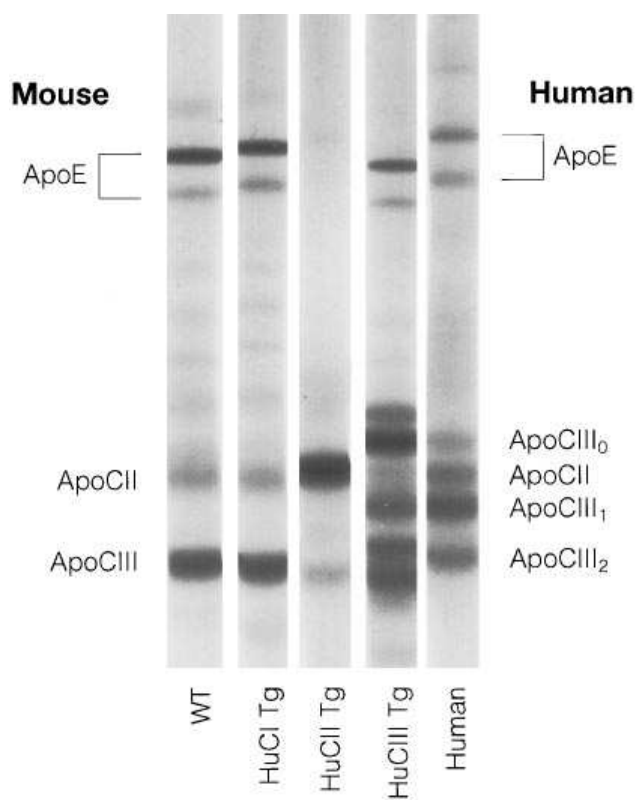

Figure 4. Isoelectric focusing of VLDL apolipoproteins from apo $\mathrm{C}$ - transgenic mice. A constant amount of protein was loaded for the mouse samples. A modest decrease in apo CII is noted in the HuCIII $\mathrm{Tg}$ sample. Apo E is markedly decreased in $\mathrm{HuCII} \mathrm{Tg}$ and moderately decreased in $\mathrm{HuCIII} \mathrm{Tg}$ mice. Apo E, apo CII, and apo CIII are all unchanged in the HuCI Tg VLDL.

The results of IEF of apolipoproteins from WT, $\mathrm{HuCI} \mathrm{Tg}$, $\mathrm{HuCII} \mathrm{Tg}$, and $\mathrm{HuCIII} \mathrm{Tg}$ mouse VLDL, as well as normal human VLDL, are shown in Fig. 4. A constant amount of protein, excluding apo B and essentially excluding apo CI, was loaded on the IEF gels. The results of densitometric analysis of the gels is shown in Table III. No changes in the ratio of apo E to apo CII or apo CIII were evident in HuCI Tg VLDL, confirming the SDS-PAGE results. HuCII Tg VLDL showed a marked decrease in apo $\mathrm{E}$, as has been previously reported (15). Apo E in HuCIII Tg VLDL was moderately decreased, as has been described (12).

Hyperlipidemia of HuCI Tg mice is associated with normal lipoprotein production but reduced clearance rates. The hypertriglyceridemia of the apo CI mice was studied using measurements of plasma triglyceride production and catabolism. Triglyceride production rates were derived by inhibiting VLDL clearance with intravenous Triton WR 1339. The rise in triglycerides over $30 \mathrm{~min}$ was $120 \pm 44.7 \mathrm{mg} / \mathrm{dl}$ in the WT mice vs

Table III. IEF of VLDL Apoproteins, Densitometry Data $(\mathrm{OD} \times \mathrm{mm})$

\begin{tabular}{lcccr}
\hline & WT & CI Tg & CII Tg & CIII Tg \\
\hline Apo E & 3.7 & 4.0 & 0.3 & 2.7 \\
Apo CII (+human apo CIII ${ }_{0}$ ) & 2.2 & 2.5 & 5.7 & 4.5 \\
Human apo CIII $_{1}$ & & & & 4.0 \\
Human apo CIII $_{2}$ & & & & 2.7 \\
Mouse apo CIII & 3.4 & 4.1 & 1.0 & 4.4 \\
Total apo C & 5.6 & 6.5 & 6.7 & 15.6 \\
Apo E/apo C & 0.7 & 0.6 & 0.1 & 0.2 \\
& & & & \\
\hline
\end{tabular}

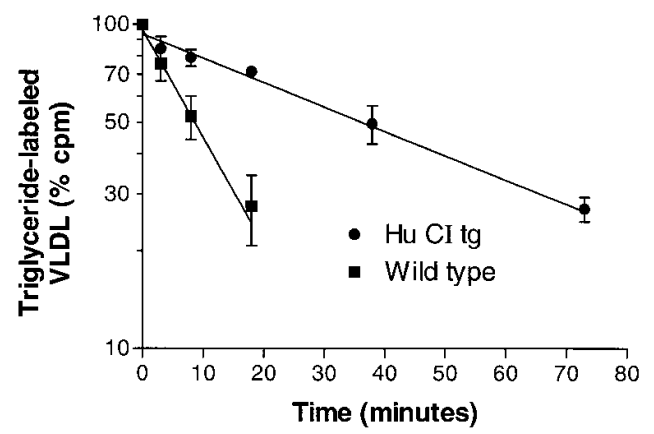

Figure 5. Clearance of VLDL triglycerides in four WT and four $\mathrm{HuCI} \mathrm{Tg}$ mice. Tracers were obtained by in vivo labeling of VLDL triglycerides in animals of the same genetic background and transgenic status. Lines represent the mean FCR of plasma cpm disappearance after the injection of in vivo-labeled VLDL. Data are normalized to the initial time point, defined as $100 \%$. The data points reflect mean normalized cpm at each time point and are in good agreement with the mean slopes. The mean fractional catabolic rate is 4.4-fold greater in the WT relative to the $\mathrm{HuCI} \mathrm{Tg}$ mice.

$112 \pm 39.5 \mathrm{mg} / \mathrm{dl}$ in the HuCI Tg mice $(n=5, P=0.76)$ arguing against a role for triglyceride overproduction. Consistent with the finding of no increase in triglyceride production, free fatty acid levels in the "fed" postabsorptive state were not significantly elevated in $\mathrm{HuCI} \mathrm{Tg}$ mice $(0.27 \pm 0.07 \mathrm{meq} / \mathrm{liter}$ in transgenics vs $0.21 \pm 0.03 \mathrm{meq} / \mathrm{liter}$ in WT, $n=5, P=0.10$ ). In contrast, the clearance of VLDL triglycerides was markedly impaired in the HuCI Tg mice (Fig. 5). The FCR of VLDL triglycerides was $4.56 \pm 1.7 \mathrm{pools} / \mathrm{h}$ for the WT animals vs $1.03 \pm 0.15 \mathrm{pools} / \mathrm{h}$ for the $\mathrm{HuCI} \mathrm{Tg}$ mice $(n=4$ for each genotype, $P<0.03)$.

Apo B kinetics were initially assessed by simultaneous measurement of apo B levels and apo B production rates, determined by intravenous injection of Triton WR 1339 and $\left[{ }^{35} \mathrm{~S}\right]$-methionine/cysteine. Baseline mouse apo B levels were increased almost twofold in the HuCI Tg mice to $106.0 \pm 39.54$ $\mu \mathrm{g} / \mathrm{ml}$ vs $59.0 \pm 9.88 \mu \mathrm{g} / \mathrm{ml}$ in WT mice $(n=5$ of each type, $P=$ $0.03)$. There was no overlap in values between the two groups.

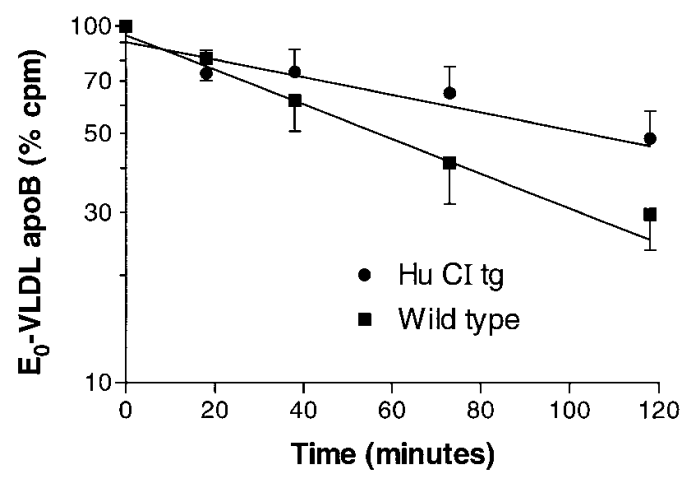

Figure 6. Clearance of apo $\mathrm{E}_{0} \mathrm{VLDL}$ apo B in WT $(n=6)$ and $\mathrm{HuCI}$ $\operatorname{Tg}(n=5)$ mice. Lines represent the mean FCR of disappearance of apo B cpm (normalized to an initial value of $100 \%$ ) after injection of radio-iodinated VLDL obtained from apo $\mathrm{E}_{0}$ mice. The data points reflect the means of all of the animals at that time point for each group. On average WT mice exhibited twofold faster clearance than $\mathrm{HuCI} \mathrm{Tg}$. 


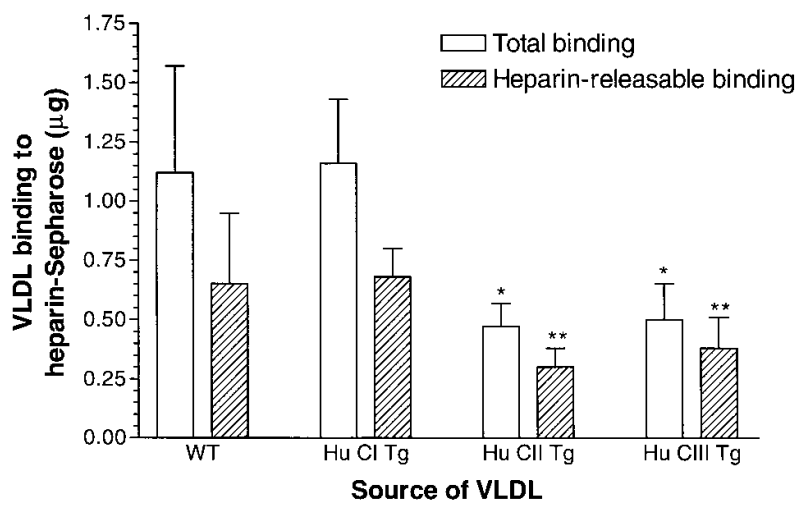

Figure 7. Binding of isolated VLDL from WT, HuCI Tg, HuCII Tg, and $\mathrm{HuCIII} \mathrm{Tg}$ mice to heparin-Sepharose. Assay was performed in triplicate for VLDL isolated from three distinct pools from each genotype. Mean total binding (as micrograms of VLDL protein) and heparin-releasable binding are shown. Both total and heparin-releasable binding are decreased in $\mathrm{HuCII} \mathrm{Tg}$ and $\mathrm{HuCIII} \mathrm{Tg}$ mice but are unchanged in HuCI Tg mice. ${ }^{*} P \leq 0.001 ; * * P \leq 0.02$.

On the other hand, apo B production rates were indistinguishable at both 60 - and $90-$ min time points. Apo B radioactivity (normalized to total plasma TCA-precipitable cpm) at $60 \mathrm{~min}$ was $336.4 \pm 52.9 \mathrm{cpm}$ for WT mice and $365.3 \pm 24.5 \mathrm{cpm}$ for HuCI Tg mice $(n=5$ of each type, $P=0.36)$. The percent change in apo B radioactivity at $90 \mathrm{~min}$ vs $60 \mathrm{~min}$ was $41.5 \pm$ $20.2 \%$ for WT mice and $53.1 \pm 33.5 \%$ for HuCI Tg mice $(n=4$ of each type, $P=0.58$ ). These results suggested that the higher apo B levels in $\mathrm{HuCI} \mathrm{Tg}$ mice were related to difference in clearance rather than production.

The clearance of apo B in remnants was estimated in control and HuCI Tg mice by measuring the FCR of a surrogate lipoprotein species, the $d<1.006$ fraction from apo $\mathrm{E}_{0}$ mice (39). These lipoproteins contain apo B48 and the C apolipoproteins and are extremely cholesterol ester-enriched and triglyceride depleted with a total cholesterol to triglyceride ratio $>3$ (27). After injection into either normal or HuCI Tg mice, the $\mathrm{E}_{0}$ remnants are presumed to acquire apo E, apo CI, and other exchangeable apolipoproteins reflective of the plasma milieu, and be cleared directly by particulate uptake mechanisms. The FCR of the labeled apo B, taken as the measure of particle clearance, was $0.66 \pm 0.19$ pools/h $(n=6)$ in control mice vs $0.34 \pm 0.16$ (pools $/ \mathrm{h})$ in apo CI transgenics $(n=5, P=$ 0.01 , Fig. 6). These data support the existence of a postlipolytic clearance defect in the $\mathrm{HuCI} \mathrm{Tg}$ mice.

HuCI Tg VLDL display no reduction in heparin-Sepharose binding affinity. In earlier work, we showed decreased affinity of HuCII Tg VLDL for heparin-Sepharose, postulated as a model for the cell surface glycosaminoglycan matrix (15). Similar studies were now performed to compare VLDL from WT, $\mathrm{HuCI} \mathrm{Tg}, \mathrm{HuCII} \mathrm{Tg}$, and HuCIII Tg mice (Fig. 7). There was no difference vs WT in the binding of HuCI Tg VLDL to heparin-Sepharose. We found that $1.12 \pm 0.45 \mu \mathrm{g}$ of WT VLDL bound the gel vs $1.16 \pm 0.27 \mu \mathrm{g}$ of HuCI Tg VLDL $(P=0.42)$. In contrast, both HuCII Tg and HuCIII Tg VLDL displayed diminished binding to heparin-Sepharose. Only $0.47 \pm 0.098 \mu \mathrm{g}$ of HuCII Tg VLDL $(P<0.001$, compared to WT) bound the gel, qualitatively similar to our published findings, although the absolute values differ due to changes in methodology. In
HuCIII Tg mice, which have not been previously examined by this technique, only $0.50 \pm 0.15 \mu \mathrm{g}$ of the VLDL bound to heparin-Sepharose $(P=0.001$, compared to WT). Direct comparisons of heparin-releasable binding, taken as a more specific indicator of VLDL binding to heparin, yielded similar results: $0.65 \pm 0.30 \mu \mathrm{g}$ for the WT vs $0.68 \pm 0.12 \mu \mathrm{g}$ for HuCI Tg $(P=$ $0.78) ; 0.30 \pm 0.078 \mu \mathrm{g}$ for HuCII Tg $(P=0.01$ vs the WT $)$; and $0.38 \pm 0.13 \mu \mathrm{g}$ for HuCIII Tg $(P=0.02$ vs the WT $)$.

\section{Discussion}

In the present study we report the creation of a liver-expressing human apo CI transgenic mouse using an apo CI gene fragment joined to the minimum liver-specific enhancer that we defined for apo E (24). The presence of the 154-bp liver-specific enhancer was sufficient to confer a high level of liver-specific expression in two transgenic lines while two lines made with the same construction lacking the enhancer did not express at all (in one line) or expressed ectopically in the intestine (in the other). This enhancer is within the region shown by Simonet et al. to be important for the liver-specific expression of both apo E and apo CI (40). The present study establishes that the same 154 bp within this region can confer robust liver-specific expression on both genes and that a larger fragment does not appear to be required, as has been recently proposed (41).

$\mathrm{HuCI} \mathrm{Tg}$ mice in the fasted state on the chow diet had about twice the normal human level of human apo CI, and were hypertriglyceridemic to about the same degree as HuCII $\mathrm{Tg}$ mice and low expressor HuCIII Tg mice. In the fed state, HuCI Tg mice exhibited only a slight further increase in triglycerides while in $\mathrm{HuCII} \mathrm{Tg}$ mice, triglycerides increased markedly (15). In further contrast to both the HuCII Tg and $\mathrm{HuCIII} \mathrm{Tg}$ lines, plasma cholesterol in HuCI Tg mice was elevated out of proportion to the increase in triglycerides $(12,15)$. A moderately high fat Western-type diet caused a relative increase (doubling) in plasma cholesterol that was the same in HuCI Tg mice as in WT controls. A large increase in human apo CI levels (threefold in the fasted state) was also noted, compared to levels on the chow diet. This increase is unlikely to be due to a transcriptional effect since mRNA levels measured by RNase protection assay were unchanged. A more likely cause is decreased catabolism of apo CI due to decreased particle clearance. Woolett, et al., using a virtually identical diet in hamsters, found a $75 \%$ decrease in LDL receptor activity, consistent with such a mechanism (42). Despite the increase in apo CI levels, there was no change, or even a possible decrease, in triglyceride concentrations. Although decreased levels of plasma triglycerides are a well-described phenomenon in mice on high fat diets (43), the lack of increase in triglycerides in the face of this marked further increase in human apo CI suggests that impaired lipolysis is not a prominent feature of this model.

Lipoprotein analysis revealed that VLDL were increased in $\mathrm{HuCI} \mathrm{Tg}$ mice and, unlike $\mathrm{HuCII} \mathrm{Tg}$ and $\mathrm{HuCIII} \mathrm{Tg}$ mice, were significantly cholesterol enriched, consistent with the impairment of remnant clearance anticipated from earlier work $(16,17)$. In contrast, a predominant lipolytic defect should have produced a decrease in the VLDL cholesterol/triglyceride ratio. Furthermore in IDL+LDL, the levels of which predominantly reflect particle clearance, cholesterol and the cholesterol/ triglyceride ratio were increased to the same extent as in VLDL. 
Apolipoprotein analysis by SDS-PAGE revealed a decrease in VLDL apo E relative to apo B that was less than that reported in high expressing $\mathrm{HuCIII} \mathrm{Tg}$ mice, which overexpressed to a greater extent and were much more hypertriglyceridemic, but in excess of that reported in low expressing HuCIII Tg mice, which were similarly hypertriglyceridemic but overexpressed to a lesser extent (12). HuCII Tg mice, which overexpressed to a greater extent than the apo CIII high expressors, appeared to have much less apo E on their VLDL. This was true despite their lesser degree of hypertriglyceridemia, which was comparable to that of HuCI Tg mice (15). Thus, human apo CI appears to be intermediate in triglyceride-elevating potency as judged by HuCII Tg mice that had human apo CII levels about seven times the normal human level and low expressor HuCIII Tg mice that had human apo CIII levels one half the normal human level (44). There was no evidence that the displacement of apo $\mathrm{E}$ in HuCI Tg VLDL was selective. The decrease in VLDL apo E/apo B detected by SDS-PAGE may reflect decreased particle size with an increased content of apo B relative to the smaller apolipoproteins as well as the increased content of apo CI.

IEF confirmed the absence of any alteration in the ratio of apo E to either apo CII or apo CIII in HuCI Tg VLDL. In contrast, the high expressing HuCIII Tg mouse VLDL did show a detectable decrease in VLDL apo E by IEF. In the case of the HuCII Tg mice, the decrease in apo E (and mouse apo CIII) was marked. Despite this marked displacement of apo E, IDL+ LDL have been reported as unchanged in HuCII Tg mice (15). Decreased apo E may be a uniform effect related to the degree of apo $\mathrm{C}$ elevation, while the (different) observed phenotypes may substantially reflect specific effects of the individual $\mathrm{C}$ apolipoproteins. Apo CI has been shown to have inhibitory effects on VLDL and IDL binding to the LDL receptor well beyond those attributable to displacement of apo E (21). Each of the $\mathrm{C}$ apolipoproteins has also been shown to interfere with the hepatic clearance of chylomicrons from estradiol-treated rats, which contained almost no apo E (45). Clearly, the modest nature of the hypertriglyceridemia observed in apo $\mathrm{E}_{0}$ mice, which entirely lack apo $E$, is further support for a role for apo $\mathrm{C}$ excess independent of the displacement of apo $\mathrm{E}$.

The apo B composition of the transgenic VLDL is also instructive. Total apo B levels were elevated, but the apo B100/ total apo B ratio of HuCI Tg VLDL was unaltered. Both apo B100 and apo B48 were therefore elevated. Only apo B100 was found in IDL+HDL, as in the WT mice. This contrasts with $\mathrm{HuCIII} \mathrm{Tg}$ mice where the apo B48/total apo B ratio is increased, apo B100 is not elevated and apo B48 is also present in IDL and LDL density ranges (13), presumably due to decreased lipolysis of chylomicrons and, possibly, decreased chylomicron remnant clearance. Similarly, in apo $\mathrm{E}_{0}$ mice, a severe chylomicron remnant clearance defect leads to an accumulation of highly cholesterol-enriched apo B48 particles in VLDL, IDL, and LDL (39). In contrast, the hypertriglyceridemia of HuCI Tg mice may reflect the effects of a remnant clearance defect that extends to apo B100 particles. Unlike the apo $\mathrm{B} 48$ particles that accumulate in the apo $\mathrm{E}_{0}$ mouse, apo B100 particles may not be as extensively lipolyzed before clearance. Indeed, human apo B transgenic mice, which show predominant elevation of apo B100, are significantly hypertriglyceridemic (46).

We tested the hypothesis of decreased remnant clearance by using radio-iodinated VLDL from apo $\mathrm{E}_{0}$ mice as a model tracer and found a significant decrease in the clearance of labeled apo B, further supporting the view that increased apo CI was associated with a defect in remnant catabolism. Apo B levels were elevated but apo B production rates were not increased, also consistent with such a mechanism. An alternative hypothesis was also considered: that the increase in VLDL, IDL, and LDL cholesterol was due to an increase in cholesterol esterification in apo B-containing particles mediated by apo CI, an LCAT activator. LCAT concentration in humans is correlated to the plasma cholesterol level, primarily cholesteryl ester in VLDL and LDL (47). In the transgenic mice, an increased fraction of the plasma cholesterol was present in VLDL and IDL+LDL. However, plasma LCAT is present only in HDL $(48,49)$ and the free/total cholesterol ratios were unchanged in the $\mathrm{HuCI} \mathrm{Tg}$ mice, arguing against an LCAT-related explanation for the increased cholesterol of HuCI Tg mice.

VLDL triglyceride kinetic studies were not fully supportive of defective remnant clearance as the sole mechanism. Triton WR 1339 studies revealed no increase in triglyceride production rates, as was anticipated. However, VLDL triglyceride clearance appeared more significantly impaired than one would expect from decreased remnant clearance alone. While this could be due to an apo CI-induced lipolytic defect, the very modest further increase in triglycerides in the fed state and the compositional data argue that decreased particle clearance is predominant. Kinetic studies are complex and it is common not to see a strict mathematical relationship between the results of kinetic studies and the static lipid measurements. The tracer does not always label the total endogenous pool, which that may lead to this discrepancy. Binding to heparinSepharose, which may reflect VLDL association with the cell surface glycosaminoglycan matrix where lipoprotein lipase and hepatic lipase reside, was the only in vitro phenomenon that appeared related to the apparent lipolytic defect in $\mathrm{HuCII} \mathrm{Tg}$ (and now HuCIII Tg) mice $(12,15)$. This measurement was unaltered in $\mathrm{HuCI} \mathrm{Tg}$ mice but the degree of displacement of apo E was less than in the HuCII and HuCIII Tg lines tested. Whether this measurement reflects the actual mechanism of action of apo $\mathrm{C}$ overexpression or only the VLDL apo E content remains uncertain.

The results of the current study, in the context of earlier work, support a possible important role for apo CI in the formation of LDL. Apo CI inhibits particulate uptake but does not interfere with glycosaminoglycan binding or, most likely, triglyceride hydrolysis of VLDL. These effects of apo CI would facilitate the conversion of VLDL to LDL in subjects with normal lipolysis. On the other hand, in individuals with marginal lipolytic competence, increased apo CI might predominantly cause an accumulation of VLDL and IDL.

Apo CI thus joins the list of genes that may be involved in the etiology of familial combined hyperlipidemia (50-55). In one population-based genetic association study, homozygosity for the minor allele of a HpaI restriction fragment length polymorphism in the apo CI promoter was found in $97 \%$ of $\epsilon 2 / \epsilon 2$ individuals with type III hyperlipidemia, $17 \%$ of normal controls and $22 \%$ of $\epsilon 2 / \epsilon 2$ individuals without hyperlipidemia (56). This polymorphism has been localized to a site $317 \mathrm{bp} 5^{\prime}$ to the apo CI transcription initiation site (25), though any possible effects on apo CI gene expression have not been reported. Further work will be needed to determine the role, if any, of apo $\mathrm{CI}$ in combined hyperlipidemia or other clinical disorders of lipoprotein metabolism. 


\section{Acknowledgments}

We thank Kristine Uffelman for expert technical assistance.

This research was supported by an American Heart Association, New York City Affiliate Investigatorship, and Grant-in-Aid to N.S. Shachter, and National Institutes of Health grants HL-21006 and HL36000 to H.N. Ginsberg. This work was done during the tenure of an Established Investigatorship from the American Heart Association to J.D. Smith.

\section{References}

1. Brown, W.V., R.I. Levy, and D.S. Frederickson. 1969. Studies of the proteins in human plasma very low density lipoproteins J. Biol. Chem. 244:56875694 .

2. Brown, W.V., R.I. Levy, and D.S. Frederickson. 1970. Further characterization of the apolipoproteins from the human plasma very low density lipoproteins. J. Biol. Chem. 245:6588-6594.

3. LaRosa, J.C., R.I. Levy, P. Herbert, S.E. Lux, and D.S. Frederickson. 1970. A specific apoprotein activator for lipoprotein lipase. Biochem. Biophys. Res. Commun. 41:57-62.

4. Havel, R.J., C.J. Fielding, T. Olivecrona, V.G. Shore, P.E. Fielding, and T. Egelrud. 1973. Cofactor activity of protein components of human very low density lipoproteins in the hydrolysis of triglycerides by lipoprotein lipase from different sources. Biochemistry. 12:1828-1833.

5. Brown, W.V., and M.L. Baginsky. 1972. Inhibition of lipoprotein lipase by an apoprotein of human very low density lipoprotein. Biochem. Biophys. Res. Commun. 46:375-382.

6. Carlson, L.A., and D. Ballantyne. 1976. Changing relative proportions of apolipoprotein C-II and C-III of very low density lipoproteins in hypertriglyceridemia. Atherosclerosis. 23:563-568.

7. Le, N.-A., J.C. Gibson, and H.N. Ginsberg. 1988. Independent regulation of plasma lipoprotein C-II and C-III concentrations in very low density and high density lipoproteins: implications for the regulation of the catabolism of these lipoproteins. J. Lipid Res. 29:669-677.

8. Wang, C.-S., W.J. McConathy, H.U. Kloer, and P. Alaupovic. 1985. Modulation of lipoprotein lipase activity by apolipoproteins. Effect of apolipoprotein C-III. J. Clin. Invest. 75:384-390.

9. Ginsberg, H.N., N.-A. Le, I.J. Goldberg, J.C. Gibson, A. Rubinstein, P. Wang-Iverson, R. Norum, and W.V. Brown. 1986. Apolipoprotein B metabolism in subjects with deficiency of apolipoproteins CIII and AI: evidence that apolipoprotein CIII inhibits catabolism of triglyceride-rich lipoproteins by lipoprotein lipase in vivo. J. Clin. Invest. 78:1287-1295.

10. Dammerman, M., L.A. Sankuijl, J. Halaas, W. Chung, and J.L. Breslow. 1993. An apolipoprotein CIII haplotype protective against hypertriglyceridemia is specified by promoter and $3^{\prime}$ untranslated region polymorphisms. Proc. Natl. Acad. Sci. USA. 90:4562-4566.

11. Ito, Y., N. Azrolan, A. O'Connell, A. Walsh, and J.L. Breslow. 1990. Hypertriglyceridemia as a result of human apo CIII gene expression in transgenic mice. Science (Wash. DC). 249:790-793.

12. Aalto-Setälä, K., E.A. Fisher, X. Chen, T. Chajek-Shaul, T. Hayek, R. Zechner, A. Walsh, R. Ramakrishnan, H.N. Ginsberg, and J.L. Breslow. 1992. Mechanism of hypertriglyceridemia in human apolipoprotein (apo) CIII transgenic mice: diminished very low density lipoprotein (VLDL) fractional catabolic rate associated with increased apo CIII and reduced apo E on the particles. J. Clin. Invest. 90:1889-1900.

13. de Silva, H.V., S.J. Lauer, J. Wang, W.S. Simonet, K.H. Weisgraber, R.W. Mahley, and J.M. Taylor. 1994. Overexpression of human apolipoprotein $\mathrm{C}$-III in transgenic mice results in an accumulation of apolipoprotein B48 remnants that is corrected by excess apolipoprotein E. J. Biol. Chem. 269:23242335 .

14. Maeda, N., H. Li, D. Lee, P. Oliver, S.H. Quarfordt, and J. Osada. 1994. Targeted disruption of the apolipoprotein C-III gene in mice results in hypotriglyceridemia and protection from postprandial hypertriglyceridemia. J. Biol. Chem. 269:23610-23616.

15. Shachter, N.S., T. Hayek, T. Leff, J.D. Smith, D.W. Rosenberg, A. Walsh, R. Ramakrishnan, I.J. Goldberg, H.N. Ginsberg, and J.L. Breslow. 1994. Overexpression of apolipoprotein CII causes hypertriglyceridemia in transgenic mice. J. Clin. Invest. 93:1683-1690.

16. Windler, E., Y. Chao, and R.J. Havel. 1980. Regulation of the hepatic uptake of triglyceride-rich lipoproteins in the rat. Opposing effects of homologous apolipoprotein $\mathrm{E}$ and individual $\mathrm{C}$ apolipoproteins. J. Biol. Chem. 255: 8303-8307.

17. Quarfordt, S.H., G. Michalopoulos, and B. Schirmer. 1982. The effect of human $\mathrm{C}$ apolipoproteins on the in vitro hepatic metabolism of triglyceride emulsions in the rat. J. Biol. Chem. 257:14642-14647.

18. Kowal, R.C., J. Herz, K.H. Weisgraber, R.W. Mahley, M.S. Brown, and J.L. Goldstein. 1990. Opposing effects of apolipoprotein E and C on lipoprotein binding to low density lipoprotein receptor-related protein. J. Biol. Chem. 265:
10771-10779

19. Weisgraber, K.H., R.W. Mahley, R.C. Kowal, J. Herz, J.L. Goldstein, and M.S. Brown. 1990. Apolipoprotein C-I modulates the interaction of apolipoprotein $E$ with $\beta$-migrating very low density lipoproteins ( $\beta-\mathrm{VLDL})$ and inhibits binding of $\beta-$ VLDL to low density lipoprotein receptor-related protein. J. Biol. Chem. 265:22453-22459.

20. Windler, E.E., P.T. Kovanen, Y.S. Chao, M.S. Brown, R.J. Havel, and J.L. Goldstein. 1980. The estradiol-stimulated lipoprotein receptor of rat liver. A binding site that membrane mediates the uptake of rat lipoproteins containing apoproteins B and E. J. Biol. Chem. 255:10464-10471.

21. Sehayek, E., and S. Eisenberg. 1991. Mechanisms of inhibition by apolipoprotein $\mathrm{C}$ of apolipoprotein E-dependent cellular metabolism of human triglyceride-rich lipoproteins through the low density lipoprotein receptor pathway. J. Biol. Chem. 266:18259-18267.

22. Simonet, W.S., N. Bucay, R.E. Pitas, S.J. Lauer, and J.M. Taylor. 1991. Multiple tissue-specific elements control the apolipoprotein E/C-I gene locus in transgenic mice. J. Biol. Chem. 266:8651-8654.

23. van Ree, J.H., M.H. Hofker, W.J. van den Broek, J.M. van Deursen, H van der Boom, R.R. Frants, B. Wieringa, and L.M. Havekes. 1995. Increased response to cholesterol feeding in apolipoprotein $\mathrm{C} 1$-deficient mice. Biochem. J. 305:905-911.

24. Shachter, N.S., Y. Zhu, A. Walsh, J.L. Breslow, and J.D. Smith. 1993. Localization of a liver-specific enhancer in the apolipoprotein E/CI/CII gene locus. J. Lipid Res. 34:1699-1708.

25. Smit, M., E. van der Kooij-Meijs, L.P. Woudt, L.M. Havekes, and R.R. Frants. 1988. Exact localization of the familial dysbetalipoproteinemia associated HpaI restriction site in the promoter region of the APOCI gene. Biochem. Biophys. Res. Commun. 152:1282-1288.

26. Walsh, A., Y. Ito, and J.L. Breslow. 1989. High levels of human apolipoprotein A-I in transgenic mice result in increased plasma levels of small high density lipoprotein (HDL) particles comparable to human $\mathrm{HDL}_{3}$. J. Biol. Chem. 264:6488-6494.

27. Plump, A.S., J.D. Smith, T. Hayek, K. Aalto-Setälä, A. Walsh, J.G. Verstuyft, E.M. Rubin, and J.L. Breslow. 1992. Severe hypercholesterolemia and atherosclerosis in apolipoprotein E-deficient mice created by homologous recombination in ES cells. Cell. 71:1-20.

28. Knott, T.J., M.E. Robertson, L.M. Priestly, M. Urdea, S. Wallis, and J. Scott. 1984. Characterisation of mRNAs encoding the precursor for human apolipoprotein CI. Nucleic Acids Res. 12:3909-3915.

29. Smith, J.D., A.S. Plump, T. Hayek, A. Walsh, and J.L. Breslow. 1990. Accumulation of human apolipoprotein $\mathrm{E}$ in the plasma of transgenic mice. $J$. Biol. Chem. 265:14709-14712.

30. Curry, M.D., W.J. McConathy, J.D. Fesmire, and P. Alaupovic. 1981. Quantitative determination of apolipoproteins C-I and C-II in human plasma by separate electroimmunoassays. Clin. Chem. 27:543-548.

31. Havel, R.J., H.A. Eder, and J.H. Bragdon. 1955. The distribution and chemical composition of ultracentrifugally separated lipoproteins in human serum. J. Clin. Invest. 34:1345-1353.

32. Herbert, P.N., R.S. Shulman, R.I. Levy, and D.S. Frederickson. 1973. Fractionation of the C-apolipoproteins from human plasma very low density lipoproteins. J. Biol. Chem. 248:4941-4946.

33. Pagnan, A., R.J. Havel, J.P. Kane, and L. Kotite. 1977. Characterization of human very low density lipoproteins containing two electrophoretic populations: double pre-beta lipoproteinemia and primary dysbetalipoproteinemia. $J$. Lipid Res. 18:613-622.

34. Ginsberg, H.N., N.-A. Le, and J.C. Gibson. 1985. Regulation of the production and catabolism of plasma low density lipoproteins in hypertriglyceridemic subjects: effect of weight loss. J. Clin. Invest. 75:614-623.

35. Bilheimer, D.W., J. Eisenberg, and R.I. Levy. 1972. The metabolism of very low density lipoproteins. I. Preliminary in vivo and in vitro observations. Biochim. Biophys. Acta. 26:212-221.

36. Levine, D.M., and K.J. Williams. 1995. Mouse apolipoprotein B: a useful screening tool for mouse models of atherosclerosis. Clin. Chem. 41:139-140. (Abstr.)

37. Attman, P.O., P. Alaupovic, and A. Gustafson. 1987. Serum apolipoprotein profile of patients with chronic renal failure. Kidney Int. 32:368-375.

38. Albers, J.J., J. Lin, and G.P. Roberts. 1979. Effect of human plasma apolipoproteins on the activity of purified lecithin: cholesterol acyltransferase. Artery. 5:61-75.

39. Plump, A.S., and J.L. Breslow. 1995. Apolipoprotein E and the apolipoprotein E-deficient mouse. Annu. Rev. Nutr. 15:495-518.

40. Simonet, W.S., N. Bucay, S.J. Lauer, and J.M. Taylor. 1993. A far-downstream hepatocyte-specific control region directs expression of the linked human apolipoprotein E and C-I genes in transgenic mice. J. Biol. Chem. 268: 8221-8229.

41. Dang, Q., D. Walker, S. Taylor, C. Allan, P. Chin, J. Fan, and J. Taylor. 1995. Structure of the Hepatic Control Region of the human apolipoprotein E/ C-I gene locus. J. Biol. Chem. 270:22577-22585.

42. Woolett, L.A., D.K. Spady, and J.M. Dietschy. 1992. Saturated and unsaturated fatty acids independently regulate low density lipoprotein receptor activity and production rate. J. Lipid Res. 33:77-88.

43. Paigen, B., A. Morrow, C. Brandon, D. Mitchell, and P. Holmes. 1985. 
Variation in susceptibility to atherosclerosis among inbred strains of mice. Atherosclerosis. 57:65-73.

44. Attman, P.-O., and P. Alaupovic. 1991. Lipid and apolipoprotein profiles of uremic dyslipoproteinemia-relation to renal function and dialysis. Nephron. 57:401-410.

45. Windler, E., and R.J. Havel. 1985. Inhibitory effects of C apolipoproteins from rats and humans on the uptake of triglyceride-rich lipoproteins and their remnants by the perfused rat liver. J. Lipid Res. 26:556-565.

46. Linton, M.F., R.W. Farese, Jr., G. Chiesa, D.S. Grass, P. Chin, R.E. Hammer, H.H. Hobbs, and S.G. Young. 1993. Transgenic mice expressing high plasma concentrations of human apolipoprotein B100 and lipoprotein(a). $J$. Clin. Invest. 92:3029-3037.

47. Kessling, A.M., M.N. Nanjee, N.E. Miller, and S.E. Humphries. 1988. Variations in the apolipoprotein AI-CIII-AIV gene region and in lecithin:cholesterol acyltransferase concentration are determinants of plasma cholesterol concentrations. Atherosclerosis. 70:13-19.

48. Glomset, J.A., E.T. Janssen, R. Kennedy, and J. Dobbins. 1966. Role of plasma lecithin:cholesterol acyltransferase in the metabolism of high density lipoproteins. J. Lipid Res. 7:638-648.

49. Fielding, P.E., and C.J. Fielding. 1980. A cholesteryl ester transfer complex in human plasma. Proc. Natl. Acad. Sci. USA. 77:3327-3330.

50. Nishina, P.M., J.P. Johnson, J.K. Naggert, and R.M. Krauss. 1992. Linkage of atherogenic lipoprotein phenotype to the low density lipoprotein receptor locus on the short arm of chromosome 19. Proc. Natl. Acad. Sci. USA. 89:
$708-712$.

51. Tybjaerg-Hansen, A., B.G. Nordestgaard, L.U. Gerdes, O. Faergeman, and S.E. Humphries. 1993. Genetic markers in the apo AI-CIII-AIV gene cluster for combined hyperlipidemia, hypertriglyceridemia, and predisposition to atherosclerosis. Atherosclerosis. 100:157-169.

52. Sijbrands, E.J., R.G. Westendorp, M.J. Hoffer, L.M. Havekes, R.R Frants, A.E. Meinders, M. Frolich, and A.H. Smelt. 1994. Effect of insulin resistance, apoE2 allele, and smoking on combined hyperlipidemia. Arterioscler. Thromb. 14:1576-1580.

53. Reynisdottir, S., M. Eriksson, B. Angelin, and P. Arner. 1995. Impaired activation of adipocyte lipolysis in familial combined hyperlipidemia. J. Clin. Invest. 95:2161-2169.

54. Mailly, F., Y. Tugrul, P.W. Reymer, T. Bruin, M. Seed, B.F. Groenemeyer, A. Asplund-Carlson, D. Vallance, A.F. Winder, G.J. Miller et al. 1995 A common variant in the gene for lipoprotein lipase (Asp9-->Asn). Functiona implications and prevalence in normal and hyperlipidemic subjects. Arterioscler. Thromb. 15:468-478.

55. Kwiterovich, P.O., Jr., M. Motevalli, and M. Miller. 1994. The effect of three serum basic proteins on the mass of lipids in normal and hyperapoB fibroblasts. Arterioscler. Thromb. 14:1-7.

56. Klasen, E.C., P.J. Talmud, L. Havekes, E. de Wit, E. van der KooijMeijs, M. Smit, G. Hansson, and S.E. Humphries. 1987. A common restriction fragment length polymorphism of the human apolipoprotein E gene and its relationship to type III hyperlipidemia. Hum. Genet. 75:244-247. 